\title{
Secondary Metabolites Produced by Macrophomina phaseolina Isolated from Eucalyptus globulus
}

\author{
Maria Michela Salvatore ${ }^{1}\left(\mathbb{D}\right.$, Carina Félix $^{2}{ }^{\mathbb{D}}$, Fernanda Lima ${ }^{2}$, Vanessa Ferreira ${ }^{2}{ }^{\circ}$, \\ Daniele Naviglio $^{1}$ (D), Francesco Salvatore ${ }^{1} \mathbb{D}$, Ana Sofia Duarte ${ }^{3} \mathbb{D}$, Artur Alves ${ }^{2}$, \\ Anna Andolfi ${ }^{1, *(\mathbb{D})}$ and Ana Cristina Esteves ${ }^{3, *}$ \\ 1 Department of Chemical Sciences, University of Naples ‘Federico II', 80126 Naples, Italy; \\ mariamichela.salvatore@unina.it (M.M.S.); naviglio@unina.it (D.N.); francesco.salvatore2@unina.it (F.S.) \\ 2 Department of Biology, CESAM, University of Aveiro, 3810-193 Aveiro, Portugal; \\ carinafelix89@gmail.com (C.F.); nandalima85@gmail.com (F.L.); fvanessa@ua.pt (V.F.); \\ artur.alves@ua.pt (A.A.) \\ 3 Faculty of Dental Medicine, Center for Interdisciplinary Research in Health (CIIS), \\ Universidade Católica Portuguesa, 3504-505 Viseu, Portugal; asduarte@viseu.ucp.pt \\ * Correspondence: andolfi@unina.it (A.A.); acesteves@viseu.ucp.pt (A.C.E.); Tel.: +39-081-253-9179 (A.A.)
}

Received: 6 February 2020; Accepted: 8 March 2020; Published: 11 March 2020

\begin{abstract}
In the course of investigations on the role of secondary metabolites in plant-microbe interactions, the production of secondary metabolites by Macrophomina phaseolina isolates from Eucalyptus globulus, was studied. This fungus is responsible for several plant diseases which affect crop productivity and industry. Although secondary metabolites may play a role in disease development, there are very few reports on M. phaseolina metabolomics and, as far as we know, isolates from eucalypts have not been investigated for secondary metabolites production. In the present paper, metabolites typical of fungi, from the family Botryosphaeriaceae, were identified for the first time as products of M. phaseolina. Furthermore, the isolate under examination was grown in the presence and absence of host stem tissue, and metabolite profiles were compared. Five products are reported for the first time in this species and azelaic acid was exclusively produced in the presence of eucalypt stem. Finally, phytotoxicity and cytotoxicity tests of culture filtrates and crude organic extracts were also performed. Key Contribution: Lipophilic metabolites produced by M. phaseolina might play a role in the plant-fungus interactions responsible for serious diseases of E. globulus.
\end{abstract}

Keywords: plant-microbe interaction; secondary metabolites; Eucalyptus globulus; Macrophomina phaseolina; plant diseases; $(3 R, 4 S)$-botryodiplodin

\section{Introduction}

The genus Eucalyptus belongs to the family Myrtaceae which contains approximately 800 species. Most Eucalyptus species are endemic to Australia and they are planted as an important source of fiber and essential oils, many of which have ecological functions as well as medicinal and industrial uses [1-4]. The remarkable adaptability of eucalypts coupled with their fast growth and wood properties has driven their rapid adoption for plantation forestry, making eucalypts the most widely planted hardwood forest trees in the world [2,5].

Due to various diseases, planting of some Eucalyptus species was impossible or limited in specific areas and it significantly affected the industry. The most serious diseases of the Eucalyptus species are caused by fungi, in particular the ones caused by Cryphonectria cubensis and various species of Mycosphaerella and Botryosphaeriaceae (e.g., Botryosphaeria dothidea, Diplodia corticola, Neofusicoccum eucalyptorum, Neofusicoccum kwambonambiense, N. parvum) [6-8]. 
Many fungi from the family Botryosphaeriaceae are well-known opportunistic pathogens of a broad number of plant hosts [9-11], being able to switch, with unfavorable environmental conditions from asymptomatic endophytes, to virulent pathogens. In fact, species of Botryosphaeriaceae are generally endophytes on eucalypts, but can also cause severe canker and dieback diseases which have negative impacts in both native and introduced plantations [12,13]. Among them, M. phaseolina (Tassi) Goid. is responsible for serious damages of eucalypt plantations $[14,15]$ and other economically important crops, such as soybean, sunflower, sesame, melon and strawberry [16-20]. In fact, M. phaseolina attacks a wide range of hosts in more than 500 cultivated and wild plant species [21]. The diseases caused by this fungus are well-documented, but few reports on secondary metabolites produced by M. phaseolina are present in the literature, although they might play a role in charcoal rot and other plant diseases. So far, M. phaseolina has been reported as a producer of only some metabolites, such as asperlin, isoasperlin, phomalactone, phaseolinic acid, phomenon and phaseolinone [22,23].

The aim of this study was to investigate, for the first time, the in vitro secondary metabolite production of an isolate of M. phaseolina from Eucalyptus globulus. The effect of eucalypt tissues on the secondary metabolite profile of M. phaseolina, grown in liquid medium, was also evaluated. Furthermore, the phytotoxic and cytotoxic activities of the culture filtrates and crude ethyl acetate extracts were also tested.

\section{Materials and Methods}

\subsection{General Experimental Procedures}

Optical rotations of pure metabolites were measured in $\mathrm{CHCl}_{3}$ or in $\mathrm{MeOH}$ on a Jasco polarimeter (Tokyo, Japan). ${ }^{1} \mathrm{H}$ NMR spectra were recorded at $400 \mathrm{MHz}$ in deuterated chloroform $\left(\mathrm{CDCl}_{3}\right)$ or in deuterated methanol $\left(\mathrm{CD}_{3} \mathrm{OD}\right)$, on Bruker spectrometers (Karlsruhe, Germany) and the same solvents were used as internal standards. Analytical and preparative TLC were performed on silica gel plates (Kieselgel 60, F254, 0.25 mm; Merck, Darmstadt, Germany). The spots were visualized by exposure to $\mathrm{UV}$ radiation $\left(253 \mathrm{~nm}\right.$ ), or by first spraying with $10 \% \mathrm{H}_{2} \mathrm{SO}_{4}$ in methanol, followed by heating at $110^{\circ} \mathrm{C}$ for $10 \mathrm{~min}$. Chromatography columns (CC) were carried out on silica gel (Merck, Kieselgel 60, $0.063-0.200 \mathrm{~mm})$.

GC-MS measurements were performed using an Agilent 6850 GC equipped with an HP-5ms capillary column (5\% phenyl methyl poly siloxane stationary phase) and the Agilent 5973 Inert MS detector (used in the scan mode). Helium was employed as the carrier gas, at a flow rate of $1 \mathrm{~mL} \mathrm{~min}{ }^{-1}$. The injector temperature was $250^{\circ} \mathrm{C}$ and the temperature ramp raised the column temperature from $70{ }^{\circ} \mathrm{C}$ to $280{ }^{\circ} \mathrm{C}: 70{ }^{\circ} \mathrm{C}$ for $1 \mathrm{~min} ; 10^{\circ} \mathrm{C} \mathrm{min}^{-1}$ until reaching $170{ }^{\circ} \mathrm{C}$; and $30^{\circ} \mathrm{C} \mathrm{min}^{-1}$ until reaching $280^{\circ} \mathrm{C}$. Then, it was held at $280^{\circ} \mathrm{C}$ for $5 \mathrm{~min}$. The electron impact (EI) ion source was operated at $70 \mathrm{eV}$ and at $200{ }^{\circ} \mathrm{C}$. The quadrupole mass filter was kept at $250{ }^{\circ} \mathrm{C}$ and was programmed to scan the range $45-550 \mathrm{~m} / \mathrm{z}$ at a frequency of $3.9 \mathrm{~Hz}$. GC-MS data were acquired on crude extracts after trimethylsilylation according to Guida et al. [24].

\subsection{Fungal Isolate and Growth Conditions}

M. phaseolina PE35 used in this study was originally isolated from E. globulus in Portugal. Cultures were maintained at room temperature on potato dextrose agar (PDA) medium (Merck, Darmstadt, Germany). Before inoculations, each isolate was cultured on PDA at $25^{\circ} \mathrm{C}$ for 7 days, in the dark. Mycelium was scraped from PDA plates and suspended in $5 \mathrm{~mL}$ of sterilized ultra-pure water. This mycelial suspension was added to $1 \mathrm{~L}$ erlenmeyers, containing $250 \mathrm{~mL}$ of potato dextrose broth (PDB) (pH 5.6), and incubated for 7 days with and without eucalypt stem (host) in the dark at $25{ }^{\circ} \mathrm{C}$. E. globulus stems were sterilized twice by autoclaving and then dried at $50{ }^{\circ} \mathrm{C}$. As a control, sterilized E. globulus stems were added to PDB and incubated for 7 days in the dark at $25^{\circ} \mathrm{C}$. Culture filtrates were obtained by filtering the culture through sterile $0.45 \mu \mathrm{m}$ cellulose acetate membranes in a vacuum system. 


\subsection{Extraction and Purification of Fungal Metabolites}

Culture filtrates $\left(\mathrm{PE} 35=1 \mathrm{~L}, \mathrm{PE} 35_{\mathrm{Host}}=1 \mathrm{~L}, \mathrm{HOST}=250 \mathrm{~mL}\right)$ were extracted 3 times with EtOAc. Each organic phase was dried with $\mathrm{Na}_{2} \mathrm{SO}_{4}$, and evaporated under reduced pressure, originating a

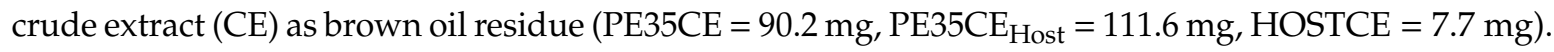
PE35 crude extracts were purified by silica gel chromatography (CC and/or TLC), producing the identified metabolites.

PE35CE was fractionated by CC on silica gel $\left(40 \mathrm{~cm} \times 1.5 \mathrm{~cm}\right.$ ID) eluted with $\mathrm{CHCl}_{3} / i-\mathrm{PrOH}(9: 1$, $v / v)$ originating 10 homogeneous fractions and the last fraction was eluted with methanol (A $0.7 \mathrm{mg}$, B $1.3 \mathrm{mg}$, C $11.0 \mathrm{mg}$, D $7.1 \mathrm{mg}$, E $1.1 \mathrm{mg}$, F $9.3 \mathrm{mg}$, G $1.9 \mathrm{mg}$, H $6.7 \mathrm{mg}$, I 6.8, L $15.0 \mathrm{mg}$ ). The residue from fraction $\mathrm{B}$, an amorphous solid, was identified as $(R)$-mellein ( $R f 0.67$ on TLC on silica gel eluted with $\mathrm{CHCl}_{3}$ ). The residue of fraction $\mathrm{C}$ was purified by preparative TLC on silica gel eluted with a mixture of $n$-hexane/EtOAc (1:1, v/v), originating an amorphous solid identified as cis-(3R,4R)-4-hydroxymellein (4.5 $\mathrm{mg} R f 0.46$ on TLC on silica gel eluted with $n$-hexane/EtOAc $(1: 1, v / v)$ ). Fraction $\mathrm{F}$, after purification by CC on silica gel $(20 \mathrm{~cm} \times 1.0 \mathrm{~cm})$ eluted with $n$-hexane/EtOAc $(1: 1, v / v)$, produced yellow oil identified as $(3 R, 4 S)$-botryodiplodin $(7.2 \mathrm{mg} R f 0.24$ on TLC on silica gel eluted with $n$-hexane/EtOAc $(1: 1, v / v))$.

PE35CE $\mathrm{CH}_{\text {Host }}$ was fractionated by CC on silica gel $\left(40 \mathrm{~cm} \times 1.5 \mathrm{~cm}\right.$ ID) eluted with $\mathrm{CHCl}_{3} / i-\mathrm{PrOH}$ $(9: 1, v / v)$, originating 9 homogeneous fractions and the last fraction was eluted with methanol (A $1.0 \mathrm{mg}$, B $2.0 \mathrm{mg}$, C $5.7 \mathrm{mg}$, D $11.6 \mathrm{mg}$, E $7.6 \mathrm{mg}$, F $14.8 \mathrm{mg}$, G $3.7 \mathrm{mg}$, H $7.1 \mathrm{mg}$, I $20.0 \mathrm{mg}$ ). The residue from fraction $\mathrm{B}$, an amorphous solid, was identified as $(R)$-mellein. The residue of fraction $\mathrm{E}$ was purified by preparative TLC on silica gel eluted with a mixture of $n$-hexane/EtOAc $(1: 1, v / v)$, originating an amorphous solid identified as cis-(3R,4R)-4-hydroxymellein $(3.2 \mathrm{mg})$. Fraction F, after purification by CC on silica gel $(20 \mathrm{~cm} \times 1.0 \mathrm{~cm}$ ID) eluted with $n$-hexane/EtOAc $(1: 1, v / v)$, produced yellow oil identified as $(3 R, 4 S)$-botryodiplodin $(10.5 \mathrm{mg})$.

\subsection{Phytotoxicity Assay}

Phytotoxicity was performed both on tomato cuttings and by a leaf puncture assay. Culture filtrates were tested on tomato cuttings using the following dilutions $(v / v): 1: 4,1: 2$, and without dilution. Tomato stems of rootless plants ( 2 weeks old) were dipped in a vial with $2 \mathrm{~mL}$ of culture filtrate. After $24 \mathrm{~h}$ of incubation at room temperature, the solution was replaced by $2 \mathrm{~mL}$ of sterile distilled water for an additional $48 \mathrm{~h}$. Sterile distilled water and PDB were used as controls. Using a $0-4$ scale $(0=$ no symptoms; 1 = slight withering; 2 = intermediate withering; 3 = severe withering; 4 = full withering), symptoms were recorded and converted to a percentage to evaluate phytotoxic activity. All assays were conducted in triplicate.

Phytotoxic activity of crude extracts was assessed by leaf puncture assay. Each tomato plant leaf was punctured with a sterile needle, and a droplet $(20 \mu \mathrm{L})$ of extract dissolved in $4 \%$ of $\mathrm{MeOH}$ was applied to the adaxial surface on the leaves. Several dilutions of extract solutions were tested: $1,0.5$, $0.25,0.1,0.01 \mathrm{mg} \mathrm{mL}^{-1}$. The leaves were kept in a moist chamber to prevent the droplets from drying and were observed daily. The visual symptoms were recorded after 10 days of incubation. The lesion diameter was expressed in $\mathrm{cm}$. All assays were carried out in triplicate.

\subsection{Cytotoxicity Assay}

The cytotoxicity tests were conducted as previously reported with slight modifications $[25,26]$. Two cell lines were grown and maintained according to Ammerman et al. [27]: A Vero cell line (ECACC 88020401, African green monkey kidney cells, GMK clone) and a 3 T3 cell line (DSMZ - ACC 173). The microtiter plates were incubated at $37^{\circ} \mathrm{C}$ in $5 \% \mathrm{CO}_{2}$ for $24 \mathrm{~h}$. Vero and $3 \mathrm{~T} 3$ cells were treated, for $20 \mathrm{~h}$, with culture filtrates or crude extracts (1:1 in DMEM-Dulbecco's modified eagle medium). Three dilutions (i.e., 1:2, 1:4, 1:8) of culture filtrates were tested. Six solutions of crude extracts were prepared in $4 \% \mathrm{MeOH}$ in phosphate buffered saline (PBS), diluted in PBS at $1-0.01 \mathrm{mg} \mathrm{mL}^{-1}$ and 
tested. PBS and $4 \% \mathrm{MeOH}$ were used as controls. After the incubation period, the medium was removed by aspiration, and $50 \mu \mathrm{L}$ of DMEM with $10 \%$ resazurin $\left(0.1 \mathrm{mg} \mathrm{mL}^{-1}\right.$ in PBS) was added to each well to assess cell viability. The microtiter plates were incubated at $37^{\circ} \mathrm{C}$ in $5 \% \mathrm{CO}_{2}$ for $3 \mathrm{~h}$. The absorbance was read at wavelengths 570 and $600 \mathrm{~nm}$ in a microtiter plate spectrophotometer (Biotek Synergy). PBS was used as the control.

\subsection{Statistical Analysis}

Two-way analysis of variance (ANOVA), followed by a Tukey multiple comparison test, was used to determine the statistical significance of cytotoxicity between each dilution/concentration and control of each crude extract or culture filtrate obtained from different sources (PE35; PE35 Host $_{\text {; host }}$ ) $(p<0.05, p<0.01, p<0.001, p<0.0001)$. All the analyses were performed with GraphPad Prism 6 (GraphPad Software, La Jolla, CA, USA). Data are shown as the average of three independent replicates of each condition.

\section{Results}

\subsection{Identification and Distribution of Metabolites}

Metabolites from PDB (potato dextrose broth) incubated with eucalypt stems, and from the culture filtrates of M. phaseolina PE35 grown with and without host tissue were extracted with ethyl acetate

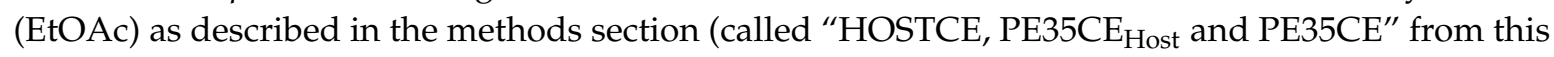
point forward). Crude extracts were treated with $\mathrm{N}, \mathrm{O}$-bis(trimethylsilyl)trifluoroacetamide (BSTFA) before GC-MS analysis because secondary metabolites may not have suitable gas chromatographic properties [28]. All metabolites were identified comparing their EI mass spectra at $70 \mathrm{eV}$ with the ones present in the NIST 14 mass spectral library [29] and the custom GC-MS library described by Félix et al. [30,31].

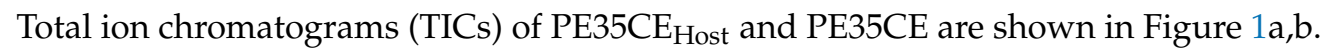

M. phaseolina PE35, under the growth conditions studied (in presence and absence of host tissue), produces $(3 R, 4 S)$-botryodiplodin, succinic acid, tyrosol, $(R)$-mellein, and cis-(3R,4R)-4-hydroxymellein. Azelaic acid was exclusively produced when M. phaseolina PE35 was grown in the presence of eucalypt stems. The definitive proof of the metabolites' identity of metabolites (Figure 2) and the stereostructure elucidation of some compounds (i.e., (3R,4S)-botryodiplodin, cis-( $3 R, 4 R)$-4-hydroxymellein and $(R)$-mellein) were obtained after fractionation by column chromatography of the crude extracts and the comparison of the ${ }^{1} \mathrm{H}$ NMR spectra and optical rotation of pure compounds with those reported in the literature [31]. 
(a)

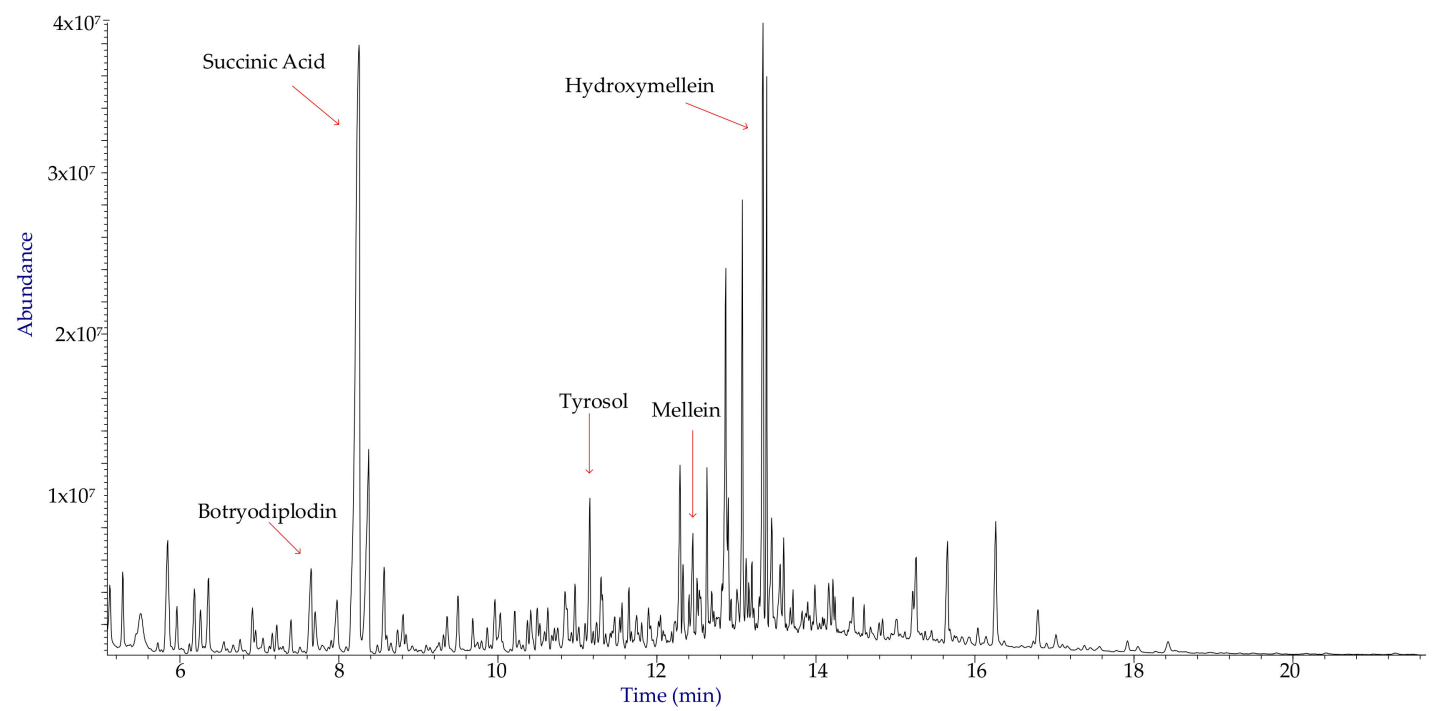

(b)

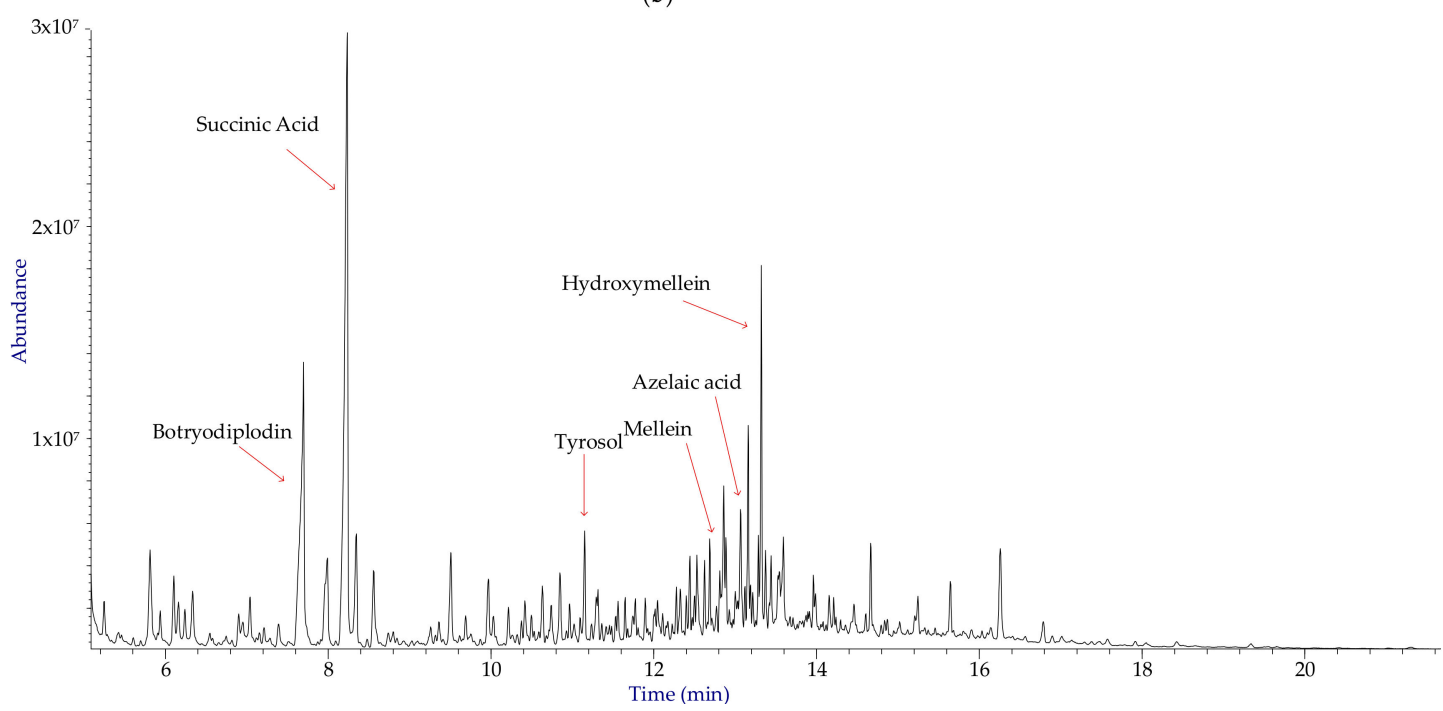

Figure 1. Annotated total ion chromatograms (TICs) acquired by processing samples from crude extracts. (a) Crude extract of Macrophomina phaseolina PE35 grown in potato dextrose broth (PDB) (PE35CE), (b) Crude extract of M. phaseolina PE35 grown in the presence of Eucalyptus globulus (PE35CE Host $_{\text {). }}$ 
<smiles>CC(=O)C1CO[C@@H](O)C1C</smiles>

$(3 R, 4 S)$-botryodiplodin<smiles>OCCc1ccc(O)cc1</smiles>

tyrosol<smiles>C[C@H]1Cc2cccc(O)c2C(=O)O1</smiles>

(R)-mellein<smiles>O=C(O)CCC(=O)O</smiles>

succinic acid<smiles>C[C@@H]1OC(=O)c2c(O)cccc2[C@H]1O</smiles>

cis-(3R,4R)-4-hy droxymellein<smiles>O=C(O)CCCCCCCC(=O)O</smiles>

azelaic acid

Figure 2. Secondary metabolites identified in crude extract of M. phaseolina PE35 grown in absence (PE35CE) and in presence of E. globulus (PE35CE $\mathrm{host}$ ). Azelaic acid was exclusively produced by M. phaseolina PE35 grown in the presence of eucalypt stems.

\subsection{Phytotoxicity and Cytotoxicity Assays}

Phytotoxicity of culture filtrates was assessed on tomato plant cuttings. Under both conditions (PE35 in the presence and in absence of host), M. phaseolina PE35 was able to induce symptoms (depigmentation and severe necrosis) on tomato plants (Figure 3). Control culture filtrate (i.e., host) showed the same effect of PDB (no visible symptoms). Comparing the results obtained from phytotoxicity tests of culture filtrates of M. phaseolina PE35 grown with and without host, no differences in toxicity were visible on tomato plants cuttings (Figure 3). Phytotoxicity (presence of symptoms) on tomato cuttings was significant only in the use of pure (undiluted) filtrate.

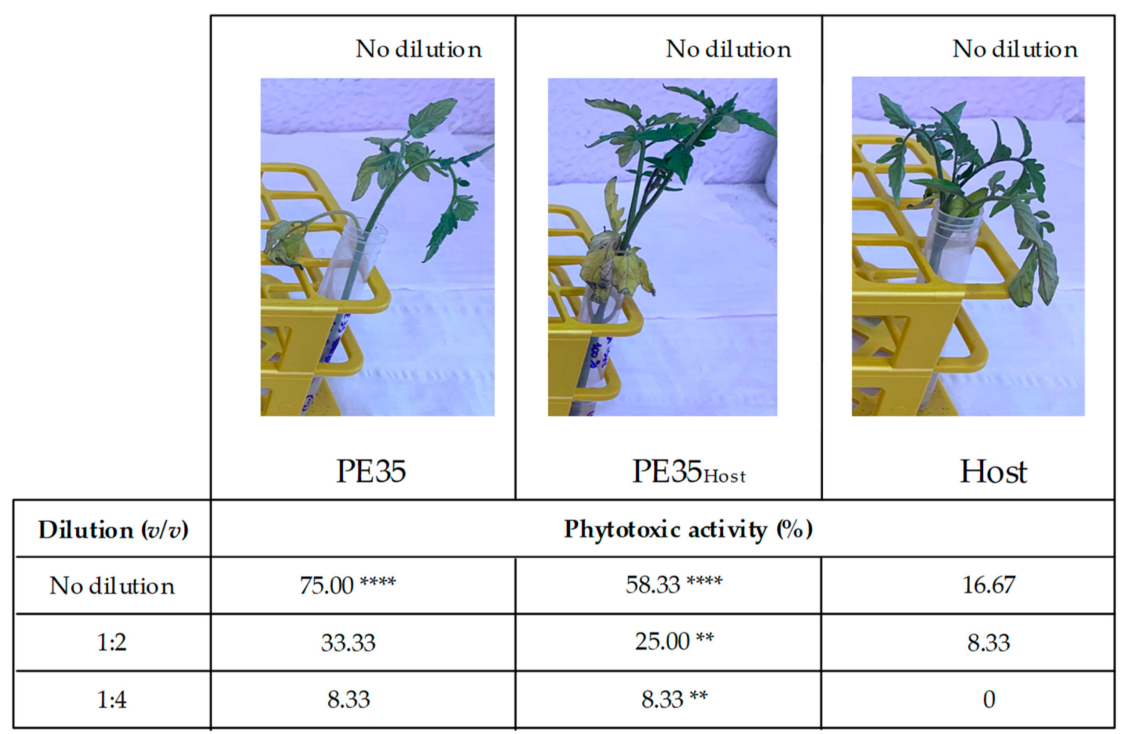

Figure 3. Phytotoxicity (\%) of culture filtrates of M. phaseolina PE35 grown with (PE35 $5_{\mathrm{Host}}$ ) and without (PE35) host tissue (eucalyptus). Two controls were used: No diluted PDB (16.67\% of phytotoxic activity) and water (no phytotoxic activity). Statistical analysis was performed using two-way ANOVA followed by a Tukey multiple comparison test. Asterisks correspond to data with statistical difference $\left({ }^{* * * *} p<0.0001,{ }^{* * *} p<0.001,{ }^{* *} p<0.01,{ }^{*} p<0.05\right)$ towards the control. 
Phytotoxicity of the crude extracts was tested on tomato leaves (Figure 4). The extracts obtained from M. phaseolina grown in the presence of the host seems to be more phytotoxic than the ones corresponding to growth without host. The crude extract of the control (i.e., HOSTCE) induced no phytotoxic symptoms (Figure 4).

\begin{tabular}{|c|c|c|c|}
\cline { 2 - 4 } & & \\
& PE35CE & PE35CEHost & HOSTCE \\
\hline $\begin{array}{c}\text { Organic extract } \\
\text { (mg mL-1) }\end{array}$ & \multicolumn{3}{|c|}{ Lesionsize (cm) } \\
\hline 1.00 & $0.48 \pm 0.08^{* * * *}$ & $0.53 \pm 0.19^{* * * *}$ & 0 \\
\hline 0.50 & $0.21 \pm 0.14^{* * * *}$ & $0.47 \pm 0.12 * * * *$ & 0 \\
\hline 0.25 & $0.16 \pm 0.16^{* * *}$ & $0.12 \pm 0.11^{* *}$ & 0 \\
\hline 0.10 & 0 & 0 & 0 \\
\hline 0.01 & 0 & 0 & 0 \\
\hline
\end{tabular}

Figure 4. Phytotoxicity of crude extracts of filtrates of M. phaseolina PE35 grown in presence (PE35CE $\mathrm{Host}_{\text {) }}$ and absence host tissue (PE35CE) and only host tissue (HOSTCE). Statistical analysis was performed using two-way ANOVA followed by a Tukey multiple comparison test. Asterisks correspond to data with statistical difference $\left({ }^{* * * *} p<0.0001,{ }^{* * *} p<0.001,{ }^{* *} p<0.01,{ }^{*} p<0.05\right)$ towards the control.

Since M. phaseolina was described as a human pathogenic opportunist [32], the toxic effect on mammalian cells was also evaluated. When the culture filtrate was assayed, it was possible to observe significant cytotoxicity on 3T3 and Vero cell lines (Figure 5).
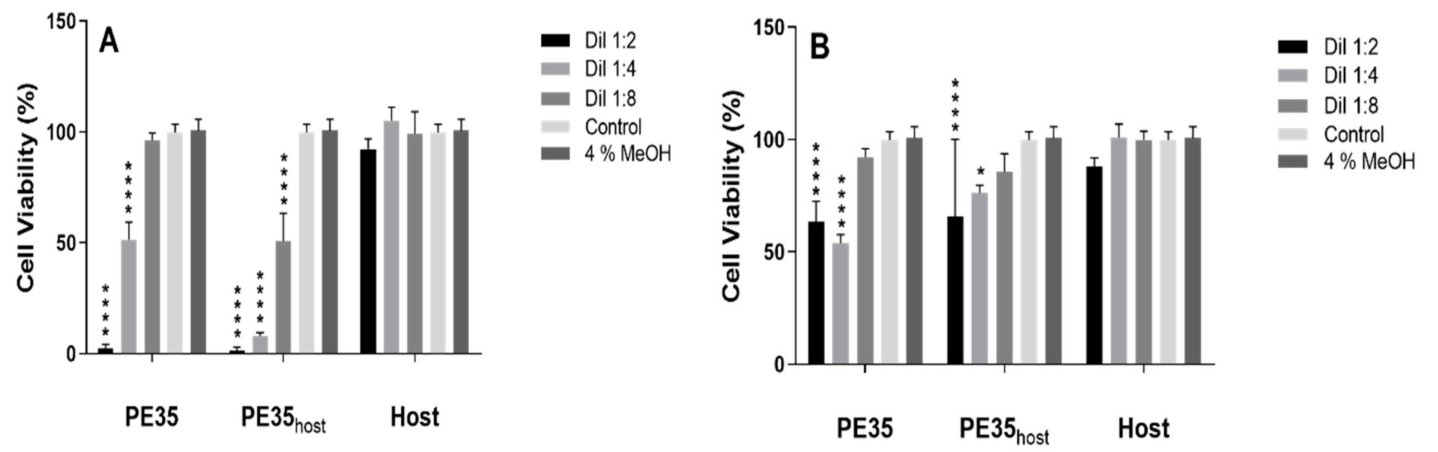

Figure 5. Cytotoxicity of culture filtrates of M. phaseolina PE35 grown with (PE35 ${ }_{\text {Host }}$ ) and without (PE35) host tissue (Eucalyptus) in 3T3 cells (A) and Vero cells (B). Phosphate buffered saline (PBS) and $4 \% \mathrm{MeOH}$ were used as the control. Statistical analysis was performed using two-way ANOVA followed by a Tukey multiple comparison test. Asterisks correspond to data with statistical difference (*** $p<0.0001, * p<0.05)$ towards the control.

Cytotoxicity data are in accordance with phytotoxicity: Both M. phaseolina extracts (PE35CE and PE35CE $\left.\mathrm{E}_{\text {host }}\right)$ induced similar phytotoxic symptoms and cell viability. Generally, both crude extracts induced higher cytotoxicity at the higher concentrations tested (Figure 6). 

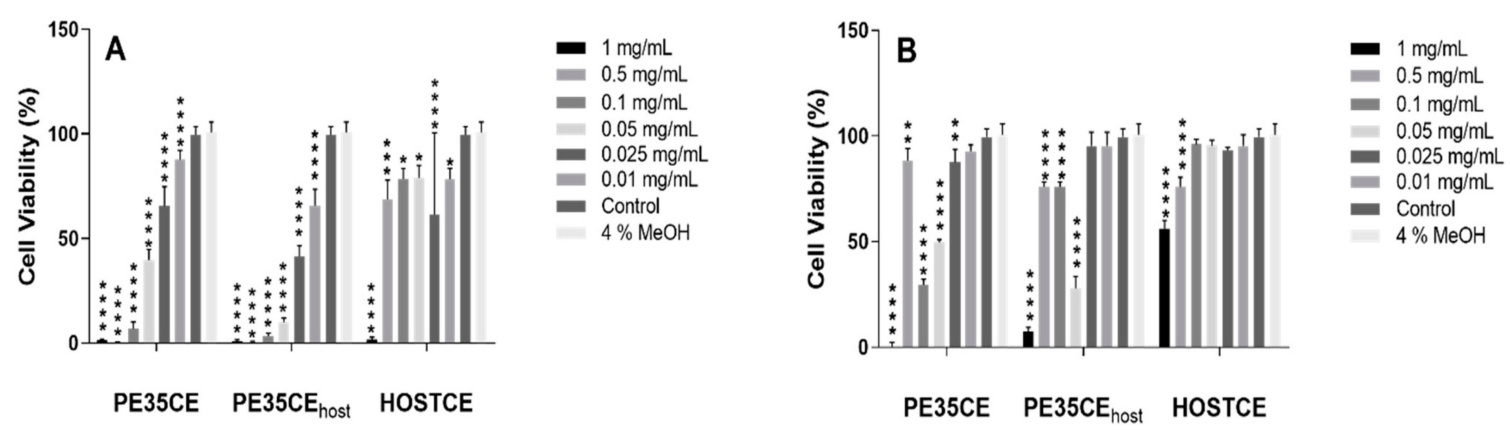

Figure 6. Cytotoxicity of crude extracts of filtrates of M. phaseolina PE35 grown in the presence

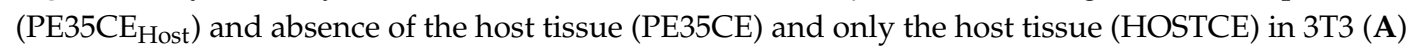
cells and Vero cells (B). Phosphate buffered saline (PBS) and $4 \% \mathrm{MeOH}$ were used as the control. Statistical analysis was performed using two-way ANOVA followed by a Tukey multiple comparison test. Asterisks correspond to data with statistical difference towards the control $\left({ }^{* * * *} p<0.0001\right.$, $\left.{ }^{* * *} p<0.001,{ }^{* *} p<0.01, * p<0.05\right)$.

\section{Discussion}

Macrophomina phaseolina, the causal agent of several plant diseases such as charcoal rot, is a threat for eucalypt crops, resulting in economic losses due to the negative effects on plant physiology $[14,15]$. Several clinical reports have also established this fungus as an opportunist human pathogen that causes infection in immunocompromised individuals [21,32-36].

Secondary metabolites produced by M. phaseolina may be correlated with disease outbreak [37], but there are very few studies on the production of compounds by this fungus $[22,23,38,39]$. We report, for the first time, the identification of secondary metabolites produced by a M. phaseolina isolate from E. globulus. Furthermore, the effect of eucalypt tissue on the secondary metabolites production was evaluated. Because M. phaseolina might be considered significant to both plant and human health [21], the culture filtrates and the crude extracts produced under both growth conditions (with and without host tissue) were evaluated for toxicity on tomato plants and on mammalian cells. The crude extracts toxicity seems to be slightly increased when the fungus was grown in presence of the host tissue.

Six metabolites, belonging to diverse classes of natural compounds were identified in the crude extracts of M. phaseolina. Azelaic acid was the only compound identified to be exclusively produced by M. phaseolina PE35 grown in the presence of the host tissue. This dicarboxylic acid was recently detected in cultures of Neofusicoccum vitifusiforme, a fungus frequently associated to Botryosphaeria dieback of grapevine [40]. Azelaic acid has antimicrobial and anti-inflammatory properties finding application in the treatment of skin diseases. Furthermore, its activity against several tumor cells has also been documented [41].

Among the identified metabolites, (3R,4S)-botryodiplodin, cis-(3R,4R)-hydroxymellein and $(R)$-mellein and tyrosol are typical metabolites produced by fungi from the family Botryosphaeriaceae [42-44], but only botryodiplodin was already known as a product of M. phaseolina. In 2007, Ramezani et al. identified the mycotoxin (3R,4S)-botryodiplodin in the culture of $M$. phaseolina, isolated from soybean [38]. Subsequently, $(3 R, 4 S)$-botryodiplodin was detected in many cultures of M. phaseolina isolated from several plants (e.g., melon, strawberry, soybean), and also as vivotoxin in studies on plant tissues naturally infected with charcoal rot disease [39].

Although it has been proposed that $(3 R, 4 S)$-botryodiplodin may be involved in the fungal infection of plants, its role in the pathogenicity remains to be clarified. Certainly, the $(3 R, 4 S)$-botryodiplodin stereostructure significantly influences the biological activities. In fact, $(3 R, 4 S)$-botryodiplodin is reported as a non-phytotoxic compound [44], but its epimer turns out to be phytotoxic and 
the cytotoxic effect of 3-epi-botryodiplodin on mammalian cells was shown to be higher than (3R,4S)-botryodiplodin [31].

Melleins are also toxic metabolites produced by fungi and could be responsible for the toxic effects of culture filtrates and crude extracts of M. phaseolina PE35 [30,31,45].

The metabolite $(3 R, 4 S)$-botryodiplodin present in crude extracts of $M$. phaseolina is responsible for high toxicity against mammalian cells (i.e., Vero and $3 \mathrm{~T} 3$ cell lines), consistent with the opportunistic nature of M. phaseolina towards the human host. In fact, it was tested for cytotoxicity on Vero and 3T3 cell lines in our previous work [31]. In general, 3T3 cells seem to be more sensitive than Vero cells when exposed to crude extracts of M. phaseolina PE35.

\section{Conclusions}

M. phaseolina is frequently associated with plant diseases and with significant economic impact on some crops (e.g., soybean, sunflower, sesame, melon) [17-20]. The present paper describes the identification of six secondary metabolites produced by M. phaseolina PE35 (isolated from E. globulus) in liquid medium. The identification of metabolites present in extracts of this isolate was carried out mainly with the support of a custom GC-MS library, but the stereostructure determinations were obtained after isolation and NMR and optical rotation analysis of metabolites. This strategy allowed the comparison of metabolite profiles obtained at different experimental conditions (i.e., presence of eucalypt stem in the liquid medium). The presence of host tissue during M. phaseolina PE35 growth induced the production of azelaic acid. The metabolomic results correspond with phytotoxicity and cytotoxicity data collected for culture filtrates and crude extracts of M. phaseolina PE35.

This work enriches the existing literature with new data on secondary metabolites by M. phaseolina. Our findings might be useful in understanding the ecology and host-pathogen relationships, the mechanisms of action of secondary metabolites and their possible application for the screening of diseases.

Author Contributions: Conceptualization, A.C.E., A.S.D., A.A. (Artur Alves) and A.A. (Anna Andolfi); methodology, A.C.E., A.S.D., A.A. (Artur Alves) and A.A. (Anna Andolfi); validation, A.C.E., A.S.D., A.A. (Artur Alves) and A.A. (Anna Andolfi); formal analysis, C.F. and F.L.; investigation, M.M.S., D.N., F.S., C.F., F.L., V.F. and A.A. (Anna Andolfi); data curation, C.F., F.L., M.M.S., V.F.; writing-original draft preparation, M.M.S., D.N., F.S., C.F., F.L., V.F.; writing-review and editing, A.C.E., A.S.D., A.A. (Artur Alves) and A.A. (Anna Andolfi); supervision, A.C.E., A.S.D., A.A.(Artur Alves) and A.A. (Anna Andolfi); project administration, A.C.E., A.S.D., A.A. (Artur Alves) and A.A. (Anna Andolfi); funding acquisition, A.A.(Artur Alves) and A.A. (Anna Andolfi). All authors have read and agreed to the published version of the manuscript.

Acknowledgments: Thanks are due to the financial support from CESAM (UID/AMB/50017/2019) and FCT/MEC through national funds and the Ministero Italiano dell'Istruzione, dell'Università e della Ricerca (MIUR) through "Finanziamento delle Attività Base della Ricerca (FFABR) 2017". Thanks are also due to FCT and UCP for the CEEC institutional financing of AC Esteves and AS Duarte (CEECINST/00137/2018).

Conflicts of Interest: The authors declare no conflict of interest.

\section{References}

1. House, S.M. Reproductive biology of eucalypts. In Eucalypt Ecology: Individuals to Ecosystems; Cambridge University Press: Cambridge, UK, 1997; pp. 30-55. ISBN 0-521-49740.

2. Coppen, J.J. Eucalyptus: The Genus Eucalyptus; CRC Press: Boca Raton, FL, USA, 2002; ISBN 0-203-21943-0.

3. Zhang, J.; An, M.; Wu, H.; Liu, D.L.; Stanton, R. Chemical composition of essential oils of four Eucalyptus species and their phytotoxicity on silverleaf nightshade (Solanum elaeagnifolium Cav.) in Australia. Plant Growth Regul. 2012, 68, 231-237. [CrossRef]

4. Dhakad, A.K.; Pandey, V.V.; Beg, S.; Rawat, J.M.; Singh, A. Biological, medicinal and toxicological significance of Eucalyptus leaf essential oil: A review. J. Sci. Food Agric. 2018, 98, 833-848. [CrossRef] [PubMed]

5. Myburg, A.A.; Potts, B.M.; Marques, C.M.; Kirst, M.; Gion, J.M.; Grattapaglia, D.; Grima-Pettenatti, J. Eucalypts. In Forest Trees; Springer: Berlin/Heidelberg, Germany, 2007; pp. 115-160. ISBN 978-3-540-34540-4.

6. Wingfield, M.J.; Slippers, B.; Hurley, B.P.; Coutinho, T.A.; Wingfield, B.D.; Roux, J. Eucalypt pests and diseases: Growing threats to plantation productivity. South For. 2008, 70, 139-144. [CrossRef] 
7. Burgess, T.I.; Wingfield, M.J. Pathogens on the move: A 100-year global experiment with planted eucalypts. Bioscience 2017, 67, 14-25. [CrossRef]

8. Barradas, C.; Phillips, A.J.; Correia, A.; Diogo, E.; Bragança, H.; Alves, A. Diversity and potential impact of Botryosphaeriaceae species associated with Eucalyptus globulus plantations in Portugal. Eur. J. Plant Pathol. 2016, 146, 245-257. [CrossRef]

9. Slippers, B.; Fourie, G.; Crous, P.W.; Coutinho, T.A.; Wingfield, B.D.; Carnegie, A.J.; Wingfield, M.J. Speciation and distribution of Botryosphaeria spp. on native and introduced Eucalyptus trees in Australia and South Africa. Stud. Mycol. 2004, 50, 343-358.

10. Phillips, A.J.L.; Alves, A.; Abdollahzadeh, J.; Slippers, B.; Wingfield, M.J.; Groenewald, J.Z.; Crous, P.W. The Botryosphaeriaceae: Genera and species known from culture. Stud. Mycol. 2013, 76, 51-167. [CrossRef]

11. Dissanayake, A.J.; Phillips, A.J.L.; Li, X.H.; Hyde, K.D. Botryosphaeriaceae: Current status of genera and species. Mycosphere 2016, 7, 1001-1073. [CrossRef]

12. Gezahgne, A.; Roux, J.; Slippers, B.; Wingfield, M.J.; Hare, P.D. Identification of the causal agent of Botryosphaeria stem canker in Ethiopian Eucalyptus plantations. S. Afr. J. Bot. 2004, 70, 241-248. [CrossRef]

13. Slippers, B.; Burgess, T.; Pavlic, D.; Ahumada, R.; Maleme, H.; Mohali, S.; Rodas, C.; Wingfield, M.J. A diverse assemblage of Botryosphaeriaceae infect Eucalyptus in native and non-native environments. South For. 2009, 71, 101-110. [CrossRef]

14. Soni, K.K.; Dadwal, V.S. Charcoal root and stem rot of Eucalyptus. Eur. J. For. Pathol. 1985, 15, $397-401$. [CrossRef]

15. Agarwal, D.K. Macrophomina: Taxonomy, Ecology, Diseases and their Management. In Taxonomy and Ecology of Indian Fungi; IK International Publishing House: New Dehli, India, 2010; pp. 59-78. ISBN 978-93-80026-92-3.

16. De, B.K.; Chattopadhya, S.B.; Arjunan, G. Effect of potash on stem rot diseases of jute caused by Macrophomina phaseolina. J. Mycopathol. Res. 1992, 30, 51-55.

17. Su, G.; Suh, S.O.; Schneider, R.W.; Russin, J.S. Host specialization in the charcoal rot fungus, Macrophomina phaseolina. Phytopathology 2001, 91, 120-126. [CrossRef] [PubMed]

18. Khan, S.N. Macrophomina phaseolina as causal agent for charcoal rot of sunflower. Mycopathology 2007, 5, 111-118.

19. Jacob, C.J.; Krarup, C.; Díaz, G.A.; Latorre, B.A. A severe outbreak of charcoal rot in cantaloupe melon caused by Macrophomina phaseolina in Chile. Plant Dis. 2013, 97, 141-142. [CrossRef]

20. Sánchez, S.; Henríquez, J.L.; Urcola, L.A.; Scott, A.; Gambardella, M. Susceptibility of strawberry cultivars to root and crown rot caused by Macrophomina phaseolina. J. Berry Res. 2016, 6, 345-354. [CrossRef]

21. Kaur, S.; Dhillon, G.S.; Brar, S.K.; Vallad, G.E.; Chand, R.; Chauhan, V.B. Emerging phytopathogen Macrophomina phaseolina: Biology, economic importance and current diagnostic trends. Crit. Rev. Microbiol. 2012, 38, 136-151. [CrossRef]

22. Dhar, T.K.; Siddiqui, K.A.; Ali, E. Structure of phaseolinone, a novel phytotoxin from Macrophomina phaseolina. Tetrahedron Lett. 1982, 23, 5459-5462.

23. Mahato, S.B.; Siddiqui, K.A.; Bhattacharya, G.; Ghosal, T.; Miyahara, K.; Sholichin, M.; Kawasaki, T. Structure and stereochemistry of phaseolinic acid: A new acid from Macrophomina phaseolina. J. Nat. Prod. 1987, 50, 245-247. [CrossRef]

24. Guida, M.; Salvatore, M.M.; Salvatore, F. A strategy for GC/MS quantification of polar compounds via their silylated surrogates: Silylation and quantification of biological amino acids. J. Anal. Bioanal. Tech. 2015, 6, 263-279.

25. Félix, C.; Duarte, A.S.; Vitorino, R.; Guerreiro, A.C.; Domingues, P.; Correia, A.C.; Alves, A.; Esteves, A.C. Temperature modulates the secretome of the phytopathogenic fungus Lasiodiplodia theobromae. Front. Plant Sci. 2016, 7, 1096.

26. Duarte, A.S.; Cavaleiro, E.; Pereira, C.; Merino, S.; Esteves, A.C.; Duarte, E.P.; Tomás, J.M.; Correia, A.C. Aeromonas piscicola AH-3 expresses an extracellular collagenase with cytotoxic properties. Lett. Appl. Microbiol. 2015, 60, 288-297. [CrossRef] [PubMed]

27. Ammerman, N.C.; Beier-Sexton, M.; Azad, A.F. Growth and maintenance of vero cell lines. Curr. Protoc. Microbiol. 2008, 11, A.4E.1-A.4E.7. [CrossRef] [PubMed]

28. Salvatore, M.M.; Nicoletti, R.; Salvatore, F.; Naviglio, D.; Andolfi, A. GC-MS approaches for the screening of metabolites produced by marine-derived Aspergillus. Mar. Chem. 2018, 206, 19-33. [CrossRef] 
29. NIST Standard Reference Data. Available online: http://www.nist.gov/srd/nist1a.cfm (accessed on 3 February 2020).

30. Félix, C.; Salvatore, M.M.; DellaGreca, M.; Meneses, R.; Duarte, A.S.; Salvatore, F.; Naviglio, D.; Gallo, M.; Jorrino-Novo, J.V.; Alves, A.; et al. Production of toxic metabolites by two strains of Lasiodiplodia theobromae, isolated from a coconut tree and a human patient. Mycologia 2018, 110, 642-653. [CrossRef] [PubMed]

31. Félix, C.; Salvatore, M.M.; DellaGreca, M.; Ferreira, V.; Duarte, A.S.; Salvatore, F.; Naviglio, D.; Gallo, M.; Alves, A.; Esteves, A.C.; et al. Secondary metabolites produced by grapevine strains of Lasiodiplodia theobromae grown at two different temperatures. Mycologia 2019, 111, 466-476. [CrossRef]

32. Schwartz, R.A.; Kapila, R. Macrophomina phaseolina: An overlooked cutaneous infection, seed rot disease in humans. Int. J. Dermatol. 2019. [CrossRef]

33. Tan, D.H.; Sigler, L.; Gibas, C.F.; Fong, I.W. Disseminated fungal infection in a renal transplant recipient involving Macrophomina phaseolina and Scytalidium dimidiatum: Case report and review of taxonomic changes among medically important members of the Botryosphaeriaceae. Med. Mycol. 2008, 46, 285-292. [CrossRef]

34. Srinivasan, A.; Wickes, B.L.; Romanelli, A.M.; Debelenko, L.; Rubnitz, J.E.; Sutton, D.A.; Thompson, E.H.; Fothergill, A.W.; Rinaldi, M.G.; Hayden, R.T.; et al. Cutaneous infection caused by Macrophomina phaseolina in a child with acute myeloid leukemia. J. Clin. Microbiol. 2009, 47, 1969-1972. [CrossRef]

35. Arora, P.; Dilbaghi, N.; Chaudhury, A. Opportunistic invasive fungal pathogen Macrophomina phaseolina prognosis from immunocompromised humans to potential mitogenic RBL with an exceptional and novel antitumor and cytotoxic effect. Eur. J. Clin. Microbiol. Infect. Dis. 2012, 31, 101-107. [CrossRef]

36. Premamalini, T.; Ambujavalli, B.T.; Vijayakumar, R.; Rajyogahandh, S.V.; Kalpana, S.; Kindo, A.J. Fungal keratitis caused by Macrophomina phaseolina a case report. Med. Mycol. Case Rep. 2012, 1, 123-126. [CrossRef]

37. Romero Luna, M.P.; Mueller, D.; Mengistu, A.; Singh, A.K.; Hartman, G.L.; Wise, K.A. Advancing our understanding of charcoal rot in soybeans. J. Integr. Pest. Manag. 2017, 8, 8. [CrossRef]

38. Ramezani, M.; Shier, W.T.; Abbas, H.K.; Tonos, J.L.; Baird, R.E.; Sciumbato, G.L. Soybean charcoal rot disease fungus Macrophomina phaseolina in Mississippi produces the phytotoxin (-)-botryodiplodin but no detectable phaseolinone. J. Nat. Prod. 2007, 70, 128-129. [CrossRef] [PubMed]

39. Abbas, H.K.; Bellaloui, N.; Accinelli, C.; Smith, J.R.; Shier, W.T. Toxin production in soybean (Glycine max L.) plants with charcoal rot disease and by Macrophomina phaseolina, the fungus that causes the disease. Toxins 2009, 11, 645. [CrossRef]

40. Salvatore, M.M.; Giambra, S.; Naviglio, D.; DellaGreca, M.; Salvatore, F.; Burruano, S.; Andolfi, A. Fatty acids produced by Neofusicoccum vitifusiforme and N. parvum, fungi associated with grapevine Botryosphaeria dieback. Agriculture 2018, 8, 189. [CrossRef]

41. Dongdong, Z.; Jin, Y.; Yang, T.; Yang, Q.; Wu, B.; Chen, Y.; Luo, Z.; Liang, L.; Liu, Y.; Xu, A.; et al. Antiproliferative and immunoregulatory effects of azelaic acid against acute myeloid leukemia via activation of notch signaling pathway. Front. Pharmacol. 2019, 10, 1396. [CrossRef] [PubMed]

42. Ramirez-Suero, M.; Benard-Gellon, M.; Chong, J.; Laloue, H.; Stempien, E.; Abou-Mansour, E.; Fontaine, F.; Larignon, P.; Mazet-Kieffer, F.; Farine, S.; et al. Extracellular compounds produced by fungi associated with Botryosphaeria dieback induce differential defence gene expression patterns and necrosis in Vitis vinifera $\mathrm{cv}$. Chardonnay cells. Protoplasma 2014, 251, 1417-1426. [CrossRef] [PubMed]

43. Andolfi, A.; Maddau, L.; Cimmino, A.; Linaldeddu, B.T.; Franceschini, A.; Serra, S.; Basso, S.; Melck, D.; Evidente, A. Cyclobotryoxide, a phytotoxic metabolite produced by the plurivorous pathogen Neofusicoccum australe. J. Nat. Prod. 2012, 75, 1785-1791. [CrossRef] [PubMed]

44. Andolfi, A.; Maddau, L.; Cimmino, A.; Linaldeddu, B.T.; Basso, S.; Deidda, A.; Serra, S.; Evidente, A. Lasiojasmonates $\mathrm{A}-\mathrm{C}$, three jasmonic acid esters produced by Lasiodiplodia sp., a grapevine pathogen. Phytochemistry 2014, 103, 145-153. [CrossRef] [PubMed]

45. Andolfi, A.; Mugnai, L.; Luque, J.; Surico, G.; Cimmino, A.; Evidente, A. Phytotoxins produced by fungi associated with grapevine trunk diseases. Toxins 2011, 3, 1569-1605. [CrossRef]

(C) 2020 by the authors. Licensee MDPI, Basel, Switzerland. This article is an open access article distributed under the terms and conditions of the Creative Commons Attribution (CC BY) license (http://creativecommons.org/licenses/by/4.0/). 